\title{
Information and Communications Technology (ICT) in Nigeria Educational Assessment System - Emerging Challenges
}

\author{
Aworanti, Olatunde Awotokun
}

National Business and Technical Examinations Board (NABTEB), Nigeria

Copyright $\bigcirc 2016$ by authors, all rights reserved. Authors agree that this article remains permanently open access under the terms of the Creative Commons Attribution License 4.0 International License

\begin{abstract}
This paper examines Information and Communications Technology (ICT) in Nigeria educational assessment system with its emerging challenges. This is inevitable following the globalisation trend which has brought drastic changes in the world of technology. The essence of the paper is to describe the present status of ICT in the Nigeria educational assessment system coupled with its emerging challenges and the strategies for overcoming the challenges. A sample of 1200 participants was drawn (300 teachers, 600 students and 300 examination personnel) from two geo-political zones by means of multistage sampling procedure. Three instruments were used for data collection namely the Teachers' Perception on Information and Communications Technology in Educational Assessment System (TPICTEAS), Students' Perception on Information and Communications Technology in Educational Assessment System (SPICTEAS), Examination Personnel' Perception on Information and Communications Technology in Educational Assessment System (EPPICTEAS). Data were collected and analysed using descriptive statistics. It was found that poor computer literacy level among teachers and students, dearth of ICT skilled personnel, inadequate ICT infrastructures and lack of fund among others are the major challenges of ICT in Nigeria educational assessment system. The study recommends the following: need for computer literacy education, need for ICT skilled personnel, provision for adequate ICT infrastructures, adequate funding among others.
\end{abstract}

Keywords Information and Communications Technology (ICT), Computer Literacy Education, Educational Assessment, Perception, Challenges

\section{Introduction}

The influence of ICT worldwide has certainly affected the field of education positively. In like manner and as a developing nation, Nigeria educational system is witnessing an optimistic transformation in this age of knowledge explosion. In the findings of Adetuyi and Oluwatayo [1], one interesting thing about ICT in the Nigeria educational system is that it serves as a transformational tool that has promoted the shift to a learner-centred environment. In the same vein, it has helped to increase access to and improve the relevance and the quality of education with a view to facilitating the acquisition and absorption of knowledge, improving policy formulation and execution and widening the range of opportunity for business and the poor. Further still, with the internet and world wide web, a wealth of learning materials in almost every subject and in a variety of media can now be accessed from anywhere at any time of the day by an unlimited number of people.

To Tinio [2], ICTs are powerful enabling tools for educational change and reform. When used appropriately, different ICTs help expand access to education, strengthen the relevance of education to the workplace, and raise educational quality by creating an active process connected to real life. David [3] asserted that ICT is paving the way for a new pedagogical approach where students are expected to play more active role than before. To Kwacha [4], ICT has made an impact on the quality and quantity of teaching, learning and research in the tradition and/or distance education institutions using it. According to Ololube, Ubogu and Ossai [5], the introduction of ICT usage, integration and diffusion has initiated a new age in educational methodologies, thus it has radically changed traditional method of information delivery and usage patterns in the domain as well as offering contemporary learning experience for both instructors and students.

To Adegbija, Fakomogbon and Daramola [6], e-examination is a welcome innovation in the Nigeria educational system due to several pitfalls in the conventional examination in the form of examination malpractices, delay and/or non-release of examination results especially where there are large classes or public examinations for candidates. As a way of curbing examination irregularities, Adegbija et al [6] highlighted some institutions that have adopted e-examination for assessing their candidates through intranet 
medium. Among such are Joint Admissions Matriculation Board (JAMB), West African Examinations Council (WAEC), National Business and Technical Examinations Board (NABTEB), National Examinations Council (NECO), National Teachers' Institute (NTI) and Teachers' Registration Council of Nigeria (TRCN). For screening of candidates, most tertiary institutions in Nigeria now use e-examinations in the Post Unified Tertiary and Matriculation Examination (Post-UTME). Further in their findings, Adegbija et al [6] identified the following universities in Nigeria that are almost fully or partially implementing the e-examination for assessing their students. These include: National Open University of Nigeria (NOUN), University of Ilorin, Ilorin, Federal University of Technology, Minna, Covenant University, Ota (Private), University of Nigeria, Nsukka, University of Lagos, Lagos. For clarification sake, only NOUN (an Open University) is fully implementing e-examinations for assessing their students through the internet.

To attest to this assertion, Taiwo and Adewuni [7] confirmed that most tertiary institutions in Nigeria now adopt e-application, e-admission and e-registration; it has equally become a field of study in Colleges of Education, Polytechnics, Monotechnics and Universities. Both science and technology of the course have become areas of specialisation to many students at undergraduate, graduate and post-graduate levels.

With all these laudable benefits of ICT to the field of education, the issue of assessment requires further inquiry as a result of challenges facing the Nigeria educational assessment system. To Ojerinde [8], assessment is at the heart of education due to the fact that test scores of assessment are used to gauge students' academic strengths and weaknesses; communities rely on these scores to judge the quality of their educational system; state and federal lawmakers use these same measure to determine whether public schools meet the goals and aspirations of those who set them hence, testing forms the bedrock of educational assessments. Aworanti [9] confirmed that, one of the most important challenges of managing educational assessment in Nigeria is the production of valid test scores and grades through institutional and public examinations established for certification purposes.

As a matter of concern, Nenty [10] asserted that a good test theory which is capable of addressing some, if not all the testing problems (such as item bias, test score equating, latent ability, scale and test construction)should be used by the examining bodies in order to ensure quality assurance in educational assessment and certification. Actually, various types of tests in the areas of educational and psychological measurements have recently become subjects of the application of Item Response Theory (IRT) which invariably serves as a product of ICT development. In view of the foregoing, this research work is being conducted to investigate the extent to which ICT has been applied to Nigeria educational assessment system, determine the emerging challenges and remedies involved in solving such challenges.

\section{Research Questions}

1. To what extent has ICT been applied to the Nigeria educational assessment system?

2. What are the emerging challenges in the application of ICT to the Nigeria educational assessment system?

3. What are the perceived remedies for overcoming the emerging challenges in ICT?

\section{Methodology}

A survey research was adopted for this study. Students and teachers in technical colleges as well as examination personnel in National Business and Technical Examinations Board (NABTEB) in Nigeria form the population for the study. In terms of sampling procedure, multistage sampling technique was used. Two geo-political zones were randomly selected out of the six geo-political zones in Nigeria. In each of the two geo-political zones randomly selected, three States were randomly selected. From each of the randomly selected six States altogether, four technical colleges were randomly selected in each State from which twenty-five students each were randomly selected. In terms of selection of teachers, fifty teachers from the four technical colleges in each State were randomly selected. As regards the examination personnel for the study one hundred and eighty examination personnel were randomly selected from six departments at the NABTEB Headquarters while twenty examination personnel were randomly selected in each of the six States. By implication, a sample of six hundred technical students, three hundred technical teachers and three hundred examination personnel was chosen for the study.

\section{Instruments}

Three instruments were used for data collection and designed by Research and Quality Assurance Department of National Business and Technical Examinations Board (NABTEB) with a view to eliciting important information related to "Information and Communications Technology (ICT) in Nigeria educational assessment system with its emerging challenges." Each of the instruments has sections $\mathrm{A}$ and $\mathrm{B}$. The instruments were:

(a). Students' Perception on Information and Communications Technology in Educational Assessment System (SPICTEAS)

(b). Teachers' Perception on Information and Communications Technology in Educational Assessment System (TPICTEAS)

(c). Examination Personnel' Perception on Information and Communications Technology in Educational Assessment System (EPPICTEAS) 
Section A of the three instruments contains background information of the participants. For the students, their background information include name of the school, gender and the class of technical study. For the teachers, this includes name of the school, gender, highest qualification and year of experience while those of the examination officers is made up of location of the State officer, gender, year of service as a NABTEB staff and highest academic qualification. Section B of each of the instruments consists of twenty-seven items. Each item contains four options in the form of Likert-scale: Strongly Agree (SA), Agree (A), Disagree (D), Strongly Disagree (SD). The validation of the instruments was done with 10 technical schools in another Geo-political zone apart from the ones for this study. Factor analysis was used to establish the construct validity of the instruments with Cronbach Alpha method. The reliability coefficients of the instruments were $0.86,0.83$ and 0.85 respectively. Any item with mean value of 2.5 and above represents positive response for selection for this study and a mean below 2.5 is neglected. Descriptive statistics were used in analysing the data collected through the instruments for this study.

\section{Results and Discussion}

\section{Research Question One}

To what extent has ICT been applied to the Nigeria educational assessment system?

Table 1. Statistics showing the application of ICT to the Nigeria educational assessment system

\begin{tabular}{|c|c|c|c|c|c|c|c|c|c|c|}
\hline \multirow{2}{*}{$\mathbf{S} / \mathbf{N}$} & \multirow[b]{2}{*}{ Statement } & \multicolumn{3}{|c|}{ Student's Response } & \multicolumn{3}{|c|}{ Teacher's Response } & \multicolumn{3}{|c|}{$\begin{array}{c}\text { Examination Personnel } \\
\text { Response }\end{array}$} \\
\hline & & Mean & $\begin{array}{l}\text { Standard } \\
\text { Deviation }\end{array}$ & Decision & Mean & $\begin{array}{l}\text { Standard } \\
\text { Deviation }\end{array}$ & Decision & Mean & $\begin{array}{l}\text { Standard } \\
\text { Deviation }\end{array}$ & Decision \\
\hline 1 & $\begin{array}{l}\text { Through ICT, on-line } \\
\text { registrations are done by } \\
\text { students in secondary and } \\
\text { tertiary institutions for } \\
\text { better assessment }\end{array}$ & 3.44 & 0.712 & Accept & 3.56 & 0.627 & Accept & 3.48 & 0.674 & Accept \\
\hline 2 & $\begin{array}{l}\text { Biometric application is } \\
\text { employed by computer } \\
\text { based institutions to } \\
\text { reduce assessment } \\
\text { manipulations }\end{array}$ & 3.24 & 0.773 & Accept & 3.19 & 0.742 & Accept & 3.20 & 0.741 & Accept \\
\hline 3 & $\begin{array}{l}\text { Closed Circuit Television } \\
\text { (CCTV) is adopted by } \\
\text { computer based } \\
\text { institutions to curb } \\
\text { examination malpractices }\end{array}$ & 3.52 & 0.715 & Accept & 3.53 & 0.629 & Accept & 3.54 & 0.578 & Accept \\
\hline 4 & $\begin{array}{l}\text { Item Response Theory } \\
\text { (IRT) soft-wares are } \\
\text { employed by computer } \\
\text { based institutions to give } \\
\text { room for better objectivity } \\
\text { in measurement of } \\
\text { educational outcomes }\end{array}$ & 3.37 & 0.754 & Accept & 3.43 & 0.596 & Accept & 3.51 & 0.623 & Accept \\
\hline 5 & $\begin{array}{c}\text { Computer Based } \\
\text { institutions make use of } \\
\text { IRT parameter estimates } \\
\text { for easy item selection in } \\
\text { test development }\end{array}$ & 3.09 & 0.781 & Accept & 3.28 & 0.557 & Accept & 3.18 & 0.678 & Accept \\
\hline 6 & $\begin{array}{l}\text { Item biases are now } \\
\text { identified to remove bad } \\
\text { items in examinations }\end{array}$ & 3.49 & 0.692 & Accept & 3.53 & 0.575 & Accept & 3.38 & 0.608 & Accept \\
\hline 7 & $\begin{array}{c}\text { Electronic test item } \\
\text { banking is in operation } \\
\text { through ICT innovations }\end{array}$ & 3.32 & 0.675 & Accept & 3.30 & 0.536 & Accept & 3.36 & 0.582 & Accept \\
\hline 8 & $\begin{array}{l}\text { Electronic examination for } \\
\text { higher leaning is in } \\
\text { operation through open } \\
\text { and distance learning }\end{array}$ & 3.22 & 0.782 & Accept & 3.30 & 0.635 & Accept & 3.31 & 0.679 & Accept \\
\hline 9 & $\begin{array}{l}\text { On-line results' checking } \\
\text { is made available through } \\
\text { ICT }\end{array}$ & 3.56 & 0.687 & Accept & 3.42 & 0.640 & Accept & 3.45 & 0.71 & Accept \\
\hline
\end{tabular}


Table 1 above indicates the perception analysis of students, teachers and examination personnel. All the mean of the study variables are above the normative mean of 2.50. This implies that all the variables are acceptable for the study in the three categories of the respondents. The variables for acceptability, therefore, include: on-line registrations are done by students in secondary and tertiary institutions for better assessment; biometric application is employed by computer based institutions to reduce assessment manipulations; Closed Circuit Television (CCTV) is adopted by computer based institutions to curb examination malpractices; Item Response Theory (IRT) soft-wares are employed by computer based institutions to give room for better objectivity in measurement of educational outcomes; Computer Based institutions make use of IRT parameter estimates for easy item selection in test development; Item biases are now identified to remove bad items in examinations Electronic test item banking is in operation through ICT innovations; Electronic examination for higher leaning is in operation through open and distance learning (NOUN) and On-line results' checking is made available through ICT

From the above results, the on-line registrations done by students in secondary and tertiary institutions for better assessment in Nigeria is an indication that the e-registration systems designed by NABTEB and all other Nigerian examination bodies for all prospective candidates are user friendly, fast, appropriate and adequate for candidates to register for their various examinations. Agbetuyi and Oluwatayo [11] stated that the introduction of on-line registration has reduced the cumbersomeness of sales of examination forms as well as completion and submission purposes; hence, the process of entry schedule in registration has been made easy and practical oriented. In terms of close circuit television, Onuka and Amusan [12] confirmed that the use of close circuit television set enables monitoring of activities of people from distance and detecting of fraudulent examination personnel. The use of item response theory software for IRT parameters and item biases has become apparent. As NABTEB makes use of X-calibre 4.2 and FastTest software for credible test development process, Ojerinde [13] corroborated the assertion that Joint Admissions Matriculation Board (JAMB) transition to IRT became expedient with the introduction of electronic item banking and computer based test (CBT). As regards, e-examination, Adegbija et al [6] identified some universities in Nigeria that are almost fully or partially implementing the e-examination for assessing their students which include: National Open University of Nigeria (NOUN), University of Ilorin, Ilorin, Federal University of Technology, Minna, Covenant University, Ota (Private), University of Nigeria, Nsukka, University of Lagos, Lagos. According to the scholars, only NOUN (an Open University) is fully implementing e-examinations for assessing their students through the internet. Furthermore, on line result checking by candidates is another means of innovation that is undoubtedly operational in NABTEB as well as other Nigerian examination bodies.

\section{Research Question Two}

What are the emerging challenges in the application of ICT to the Nigeria educational assessment system?

Table 2. Statistics showing the emerging challenges in the application of ICT to the Nigeria educational assessment system

\begin{tabular}{|c|c|c|c|c|c|c|c|c|c|c|}
\hline \multirow{2}{*}{$\mathbf{S} / \mathbf{N}$} & \multirow[b]{2}{*}{ Statement } & \multicolumn{3}{|c|}{ Student's Response } & \multicolumn{3}{|c|}{ Teacher's Response } & \multicolumn{3}{|c|}{$\begin{array}{c}\text { Examination Personnel } \\
\text { Response }\end{array}$} \\
\hline & & Mean & Agree & Disagree & Mean & Agree & Disagree & Mean & Agree & Disagree \\
\hline 1. & $\begin{array}{l}\text { Lack of ICT literacy among } \\
\text { teachers affects its utmost use in } \\
\text { schools }\end{array}$ & 3.23 & $\begin{array}{c}493 \\
82.2 \%\end{array}$ & $\begin{array}{c}107 \\
17.8 \%\end{array}$ & 3.42 & $\begin{array}{c}278 \\
92.7 \%\end{array}$ & $\begin{array}{c}22 \\
7.3 \%\end{array}$ & 3.42 & $\begin{array}{c}287 \\
95.6 \%\end{array}$ & $\begin{array}{c}13 \\
4.4 \%\end{array}$ \\
\hline 2. & Inadequate ICT training facilities & 3.16 & $\begin{array}{c}489 \\
81.5 \% \\
\end{array}$ & $\begin{array}{c}111 \\
18.5 \% \\
\end{array}$ & 3.23 & $\begin{array}{r}259 \\
86.3 \% \\
\end{array}$ & $\begin{array}{c}41 \\
13.7 \% \\
\end{array}$ & 3.35 & $\begin{array}{r}279 \\
93 \% \\
\end{array}$ & $\begin{array}{c}21 \\
7 . \% \\
\end{array}$ \\
\hline 3. & $\begin{array}{l}\text { Inappropriate funding hinders the } \\
\text { maximum use of ICT facilities for } \\
\text { assessment in schools }\end{array}$ & 3.29 & $\begin{array}{c}511 \\
85.2 \%\end{array}$ & $\begin{array}{c}89 \\
14.8 \%\end{array}$ & 3.37 & $\begin{array}{l}273 \\
91 \%\end{array}$ & $\begin{array}{l}27 \\
9 \%\end{array}$ & 3.46 & $\begin{array}{c}284 \\
94.7 \%\end{array}$ & $\begin{array}{c}16 \\
5.3 \%\end{array}$ \\
\hline 4. & $\begin{array}{c}\text { There are few highly skilled } \\
\text { personnel to operate complex ICT } \\
\text { facilities for assessment processes }\end{array}$ & 3.20 & $\begin{array}{l}486 \\
81 \%\end{array}$ & $\begin{array}{c}114 \\
19 \%\end{array}$ & 3.36 & $\begin{array}{c}268 \\
89.3 \%\end{array}$ & $\begin{array}{c}32 \\
10.7 \%\end{array}$ & 3.25 & $\begin{array}{c}267 \\
89.7 \%\end{array}$ & $\begin{array}{c}33 \\
11 \%\end{array}$ \\
\hline 5. & $\begin{array}{l}\text { Unwilling to change from the old } \\
\text { system of testing to more } \\
\text { innovative and technology based } \\
\text { assessment methods }\end{array}$ & 3.30 & $\begin{array}{c}519 \\
86.5 \%\end{array}$ & $\begin{array}{c}81 \\
13.5 \%\end{array}$ & 3.34 & $\begin{array}{c}266 \\
88.7 \%\end{array}$ & $\begin{array}{c}34 \\
11.3 \%\end{array}$ & 3.14 & $\begin{array}{c}248 \\
82.7 \%\end{array}$ & $\begin{array}{c}52 \\
17.3 \%\end{array}$ \\
\hline 6. & High cost of ICT facilities: & 3.27 & $\begin{array}{c}506 \\
84.3 \% \\
\end{array}$ & $\begin{array}{c}94 \\
15.7 \% \\
\end{array}$ & 3.40 & $\begin{array}{c}277 \\
92.3 \% \\
\end{array}$ & $\begin{array}{c}23 \\
7.7 \% \\
\end{array}$ & 3.42 & $\begin{array}{c}278 \\
93.7 \% \\
\end{array}$ & $\begin{array}{c}22 \\
6.3 \% \\
\end{array}$ \\
\hline 7. & $\begin{array}{l}\text { Access to internet connectivity is } \\
\text { limited in remote areas }\end{array}$ & 3.24 & $\begin{array}{c}505 \\
84.2 \%\end{array}$ & $\begin{array}{c}95 \\
15.8 \%\end{array}$ & 3.20 & $\begin{array}{c}245 \\
81.7 \%\end{array}$ & $\begin{array}{c}55 \\
18.3 \%\end{array}$ & 3.23 & $\begin{array}{l}249 \\
83 \%\end{array}$ & $\begin{array}{c}51 \\
17 \%\end{array}$ \\
\hline 8. & $\begin{array}{l}\text { Limited knowledge-ability of Item } \\
\text { Response Theory soft-wares for } \\
\text { assessment purposes }\end{array}$ & 3.25 & $\begin{array}{c}502 \\
83.7 \%\end{array}$ & $\begin{array}{c}98 \\
16.3 \%\end{array}$ & 3.21 & $\begin{array}{c}254 \\
84.7 \%\end{array}$ & $\begin{array}{c}46 \\
15.3 \%\end{array}$ & 3.14 & $\begin{array}{c}239 \\
89.7 \%\end{array}$ & $\begin{array}{c}61 \\
20.3 \%\end{array}$ \\
\hline 9. & $\begin{array}{l}\text { Unstable electricity supply affects } \\
\text { the use of ICT }\end{array}$ & 3.71 & $\begin{array}{c}526 \\
87.6 \% \\
\end{array}$ & $\begin{array}{c}74 \\
12.4 \% \\
\end{array}$ & 3.52 & $\begin{array}{c}280 \\
93.4 \% \\
\end{array}$ & $\begin{array}{c}20 \\
6.6 \% \\
\end{array}$ & 3.59 & $\begin{array}{l}288 \\
96 \% \\
\end{array}$ & $\begin{array}{c}12 \\
4 \% \\
\end{array}$ \\
\hline
\end{tabular}


From table 2 above, over $80 \%$ of the students, teachers and examination personnel for this study attest to the following emerging challenges in the application of ICT to the Nigerian educational assessment system: Lack of ICT literacy among teachers affects its utmost use in schools; inadequate ICT training facilities; inappropriate funding hinders the maximum use of ICT facilities for assessment in schools; there are few highly skilled personnel to operate complex ICT facilities for assessment processes; unwilling to change from the old system of testing to more innovative and technology based assessment methods; high cost of ICT facilities:; access to internet connectivity is limited in remote areas; delay in operations for ICT institutions relying on firms for operational works and unstable electricity supply affects the use of ICT.

The above result was confirmed by Ekpenyong, Ogbeide and Robinson [14] with the fact that there is a shortage of trained personnel in application of software, operating systems, network administration and technicians to service and repair computer facilities. To corroborate this, Adomi, Omodeko and Otolo [15] asserted that as a developing country also, electricity failure has been a persistent problem militating against ICT application and use in Nigeria. This prevents the few schools with ICT facilities to use them regularly. Unstable electricity makes information, communication and technology impossible - that is, Data cannot be processed, analysed, interpreted and made meaningful to receiver of a message. Information cannot be transferred from one source/person to another and civilized life of higher standard of living cannot be achieved.

\section{Research Question Three}

What are the perceived remedies for overcoming the emerging challenges in ICT?

Table 3 depicts the perceived remedies for overcoming the emerging challenges in ICT from the perception of students, teachers and examination personnel as follows. Need for computer literacy education $(92.6 \%, 97.3 \%$ and $94.3 \%)$; Need for technically trained IRT personnel in areas of test development (93\%, 96.7\% and 94.6\%); Adequate funding should be provided by the government $(92.5 \%, 94.7 \%$ and $89 \%$ ); Provision of adequate ICT infrastructures $(79.5 \%$, $83.7 \%$ and $85.4 \%$ ) Periodic IRT training workshops and seminars on item development process skills $(88.6 \%, 93 \%$ and 89.6\%); Philanthropist sponsor-ship should be encouraged to provide computer laboratories in schools (87\%, 91\% and 92.3\%); Public-Private-Partner-ship should be encouraged to equip computer laboratories in schools. (79\%, 83.7\% and $85.4 \%)$; Old students association should be encouraged to provide ICT facilities for their alma-mater $(62 \%, 72 \%$ and $61 \%)$; ICT should be introduced into the basic educational systems in Nigeria $(68.5 \%, 77.7 \%$ and $73.6 \%)$

Table 3. Statistics showing the perceived remedies for overcoming the emerging challenges in ICT

\begin{tabular}{|c|c|c|c|c|c|c|c|c|c|c|}
\hline \multirow{2}{*}{$\mathbf{S} / \mathbf{N}$} & & \multicolumn{3}{|c|}{ Student's Response } & \multicolumn{3}{|c|}{ Teacher's Response } & \multicolumn{3}{|c|}{$\begin{array}{c}\text { Examination Personnel } \\
\text { Response }\end{array}$} \\
\hline & Statement & Mean & Agree & Disagree & Mean & Agree & Disagree & Mean & Agree & Disagree \\
\hline 1 & $\begin{array}{c}\text { Need for computer literacy } \\
\text { education }\end{array}$ & 3.54 & $\begin{array}{c}556 \\
92.6 \%\end{array}$ & $\begin{array}{c}44 \\
7.4 \%\end{array}$ & 3.63 & $\begin{array}{c}292 \\
97.3 \%\end{array}$ & $\begin{array}{c}8 \\
2.7 \%\end{array}$ & 3.55 & $\begin{array}{c}283 \\
94.3 \%\end{array}$ & $\begin{array}{c}17 \\
5.7 \%\end{array}$ \\
\hline 2 & $\begin{array}{l}\text { Need for technically } \\
\text { trained IRT personnel in } \\
\text { areas of test development }\end{array}$ & 3.54 & $\begin{array}{c}558 \\
93 \%\end{array}$ & $\begin{array}{l}42 \\
7 \%\end{array}$ & 3.55 & $\begin{array}{c}289 \\
96.7 \%\end{array}$ & $\begin{array}{c}11 \\
3.7 \%\end{array}$ & 3.57 & $\begin{array}{c}284 \\
94.6 \%\end{array}$ & $\begin{array}{c}16 \\
5.4 \%\end{array}$ \\
\hline 3 & $\begin{array}{l}\text { Adequate funding should } \\
\text { be provided by the } \\
\text { government }\end{array}$ & 3.52 & $\begin{array}{c}555 \\
92.5 \%\end{array}$ & $\begin{array}{c}45 \\
7.5 \%\end{array}$ & 3.53 & $\begin{array}{c}284 \\
94.7 \%\end{array}$ & $\begin{array}{c}16 \\
5.3 \%\end{array}$ & 3.41 & $\begin{array}{l}267 \\
89 \%\end{array}$ & $\begin{array}{c}33 \\
11 \%\end{array}$ \\
\hline 4 & $\begin{array}{l}\text { Provision of adequate ICT } \\
\text { infrastructures }\end{array}$ & 3.04 & $\begin{array}{c}487 \\
79.5 \%\end{array}$ & $\begin{array}{c}113 \\
20.5 \%\end{array}$ & 3.17 & $\begin{array}{c}251 \\
83.7 \%\end{array}$ & $\begin{array}{c}49 \\
16.3 \%\end{array}$ & 3.18 & $\begin{array}{c}256 \\
85.4 \%\end{array}$ & $\begin{array}{c}44 \\
14.6 \%\end{array}$ \\
\hline 5 & $\begin{array}{c}\text { Periodic IRT training } \\
\text { workshops and seminars on } \\
\text { item development process } \\
\text { skills }\end{array}$ & 3.36 & $\begin{array}{c}532 \\
88.6 \%\end{array}$ & $\begin{array}{c}68 \\
11.4 \%\end{array}$ & 3.46 & $\begin{array}{l}279 \\
93 \%\end{array}$ & $\begin{array}{l}21 \\
7 \%\end{array}$ & 3.40 & $\begin{array}{l}269 \\
89.6\end{array}$ & $\begin{array}{c}31 \\
10.4 \%\end{array}$ \\
\hline 6 & $\begin{array}{l}\text { Philanthropist sponsor-ship } \\
\text { should be encouraged to } \\
\text { provide computer } \\
\text { laboratories in schools }\end{array}$ & 3.27 & $\begin{array}{l}520 \\
87 \%\end{array}$ & $\begin{array}{c}80 \\
13 \%\end{array}$ & 3.36 & $\begin{array}{l}273 \\
91 \%\end{array}$ & $\begin{array}{l}27 \\
9 \%\end{array}$ & 3.40 & $\begin{array}{c}277 \\
92.3 \%\end{array}$ & $\begin{array}{c}23 \\
7.7 \%\end{array}$ \\
\hline 7 & $\begin{array}{l}\text { Public-Private-Partner-ship } \\
\text { should be encouraged to } \\
\text { equip computer } \\
\text { laboratories in schools. }\end{array}$ & 3.33 & $\begin{array}{c}544 \\
92.3 \%\end{array}$ & $\begin{array}{c}56 \\
7.7 \%\end{array}$ & 3.32 & $\begin{array}{l}270 \\
90 \%\end{array}$ & $\begin{array}{c}30 \\
10 \%\end{array}$ & 3.36 & $\begin{array}{c}283 \\
94.3 \%\end{array}$ & $\begin{array}{c}17 \\
5,7 \%\end{array}$ \\
\hline 8 & $\begin{array}{l}\text { Old students association } \\
\text { should be encouraged to } \\
\text { provide ICT facilities for } \\
\text { their alma-mater }\end{array}$ & 2.59 & $\begin{array}{l}372 \\
62 \%\end{array}$ & $\begin{array}{l}228 \\
38 \%\end{array}$ & 2.72 & $\begin{array}{l}186 \\
72 \%\end{array}$ & $\begin{array}{c}114 \\
38 \%\end{array}$ & 2.67 & $\begin{array}{c}184 \\
61.3 \%\end{array}$ & $\begin{array}{c}11.6 \\
38.7 \%\end{array}$ \\
\hline 9 & $\begin{array}{l}\text { ICT should be introduced } \\
\text { into the basic educational } \\
\text { systems in Nigeria }\end{array}$ & 2.91 & $\begin{array}{c}411 \\
68.5 \%\end{array}$ & $\begin{array}{c}199 \\
31.5 \%\end{array}$ & 3.05 & $\begin{array}{c}233 \\
77.7 \%\end{array}$ & $\begin{array}{c}67 \\
22.3 \%\end{array}$ & 2.97 & $\begin{array}{c}221 \\
73.6 \%\end{array}$ & $\begin{array}{c}79 \\
26.4 \%\end{array}$ \\
\hline
\end{tabular}


Based on these perceived remedies among others, it can be said that if all the various aspects of the remedies are well encouraged, the prospect of ICT in the Nigeria educational assessment system will allow for quality operations of assessment of students, teachers and the educational programmes for better productivity and creativity in this age of knowledge explosion.

\section{Conclusions}

The present era of technological explosion has immensely popularized the use of Information and Communications Technology to enhance teaching and learning activities as well as assessment and certification processes. There is no doubt therefore that giving attention to those remedies as discussed in this paper would not only address the challenges confronting the use of ICT but also prevent the re-occurrence of such impediments to efficient and effective use of it. Hence, the identified challenges are not strong enough to discourage the assessment bodies from embracing the efficacy of Information and Communications Technology for enhancement of their operations.

\section{Recommendations}

The study recommends the following:

a) There is need for computer literacy education

b) ICT skilled personnel should be adequately provided for by all examination bodies

c) There is need for adequate ICT infrastructures

d) Adequate funding should be made available by the tiers of the government.

\section{REFERENCES}

[1] P.A. Agbetuyi, and J.A. Oluwatayo, Information and Communications Technology (ICT) in Nigeria educational system Mediterranean. Journal of Social Sciences, Vol. 3, No. 3, 2012 .

[2] V.L. Tinio, ICT in education. Online available from http://www.eprimers.org

[3] M. David, Three aspects of ICT in education. Online available from http://otec.illeregen.edu/ICTuo.html

[4] P.Z. Kwacha, The imperative of Information and Communication Technologies for teachers in Nigeria higher education. Merlot Journal of online learning and teaching, Vol. 3, No. 4, 2007.

[5] N.P. Ololube, A.E. Ubogu, and A.G. Ossai, ICT and distance education in Nigeria. A review of literature and accounts. International Open and Distance Learning (IODL) Symposium, 2007.

[6] M.V. Adegbija, M.A. Fakomogbon, and F.O. Daramola, The new technologies and the conduct of e-examinations: A case study of National Open University of Nigeria. British Journal of Science, Vol.3, No. 59, 2012.

[7] M.B. Taiwo, and S.O. Adewuni, Trend analysis of candidates' enrolment in NABTEB Information and Communications Technology: A paper presented during the 2nd Institute of Education international conference, 2013, June 4 and 7, University of Ibadan, Ibadan, Nigeria.

[8] D. Ojerinde, Using assessment for the improvement of tertiary education in Nigeria: the Joint Admissions and Matriculation Board (JAMB) role. A paper presented at the 35th IAEA conference in 2009, Brisbane, Ausralia.

[9] O.A. Aworanti, Transforming public examining system through the application of latent trait models. A paper presented during the 2nd Institute of Education international conference, 2013 June 4 and 7, University of Ibadan, Ibadan, Nigeria.

[10] H.J. Nenty, Advances in test validation. In G.A. Badmus, and P. I. Odor (Eds.), Challenges of managing educational assessment in Nigeria. Kaduna, Nigeria: National Conference on Educational Assessment, 1996.

[11] P.A. Agbetuyi and J.A. Oluwatayo, Information and communication technology in Nigerian educational system. Mediterranian Journal of Social Sciences, Vol.3, No. 3, 41-45, 2012.

[12] A.O.U Onuka and M.A. Amusan, Causes, effects and probable solutions to examination malpractices: A case study of the West African Examination Council Examinations in Abeokuta. Ghana Journal of Teaching Vol. 1, No. 8, 2008.

[13] D. Ojerinde, Innovations in assessment: JAMB Experience. A keynote address presented at the 16th Annual National Conference of the Association of Educational Researchers and Evaluators of Nigeria (ASSEREN) held at International Conference Centre, July 14 and 18, University of Calabar, Calabar, Nigeria.

[14] L.E. Ekpenyong, I.G. Ogbeide, and O.O. Robinson, Emerging challenges in Information and Communications Technology in Business Education in Association of Business Educators of Nigeria book for readings Vol. 2, No. 1, issue 12, 2012.

[15] E.E. Adomi, F.S. Omodeko, and P.U. Otdo, The use of cybercafé at Delta State University, Abraka, Nigeria. Library Hi Tech, Vol. 22, No.4, 383-88, 2004. 